\title{
Archaeological Survey of Bandera City Park, Bandera County, Texas
}

Ronald W. Burkett

Follow this and additional works at: https://scholarworks.sfasu.edu/ita

Part of the American Material Culture Commons, Archaeological Anthropology Commons, Environmental Studies Commons, Other American Studies Commons, Other Arts and Humanities Commons, Other History of Art, Architecture, and Archaeology Commons, and the United States History Commons

Tell us how this article helped you.

This Article is brought to you for free and open access by the Center for Regional Heritage Research at SFA ScholarWorks. It has been accepted for inclusion in Index of Texas Archaeology: Open Access Gray Literature from the Lone Star State by an authorized editor of SFA ScholarWorks. For more information, please contact cdsscholarworks@sfasu.edu. 


\section{Archaeological Survey of Bandera City Park, Bandera County, Texas}

Creative Commons License

(c) (i) (8)

This work is licensed under a Creative Commons Attribution-NonCommercial 4.0 International License 


\title{
ARCHAEOLOGICAL SURVEY OF BANDERA CITY PARK, BANDERA COUNTY, TEXAS
}

\author{
Ronald W. Burkett
}

Center for Archaeological Research The University of Texas at San Antonio Archaeological Survey Report, No. 183 





\title{
ARCHAEOLOGICAL SURVEY OF BANDERA CITY PARK, BANDERA COUNTY, TEXAS
}

\author{
Ronald W. Burkett \\ Submitted to Raymond Adamietz, Mayor \\ City of Bandera
}

Texas Antiquities Committee Permit No. 726

Center for Archaeological Research The University of Texas at San Antonio ${ }^{\circledR}$ Archaeological Survey Report, No. 183 
The following information is provided in accordance with the General Rules of Practice and Procedure, Chapter 41.11 (Investigative Reports), Texas Antiquities Committee:

1. Type of investigation: survey and limited subsurface testing;

2. Project name: Bandera City Park;

3. County: Bandera;

4. Principal investigator: Jack D. Eaton;

5. Name and location of sponsoring agency: Office of the Mayor, City of Bandera, Texas;

6. Texas Antiquities Committee Permit No. 726;

7. Prepared by the Center for Archaeological Research, The University of Texas at San Antonio, 78258-0658, 1989.

A list of publications offered by the Center for Archaeological Research can be obtained by sending $\$ 1.00$ to the Center for Archaeological Research, The University of Texas at San Antonio, Texas 78285-0658. 


\begin{abstract}
On September 23, 1988, a cultural resources survey was conducted within the proposed boundaries of Bandera City Park, Bandera County, Texas. The archaeological survey was conducted in accordance with the National Historic Preservation Act of 1966, as amended, and the Texas Antiquities Code. As a result of a systematic pedestrian survey of the planned 150-acre park, one prehistoric site (41 BN 94) was identified. Because of the extensive natural disturbance to the locale, no further work is recommended at site $41 \mathrm{BN} 94$. It is not considered potentially eligible for nomination to the National Register of Historic Places or as a State Archeological Landmark.
\end{abstract}




\section{TABLE OF CONTENTS}

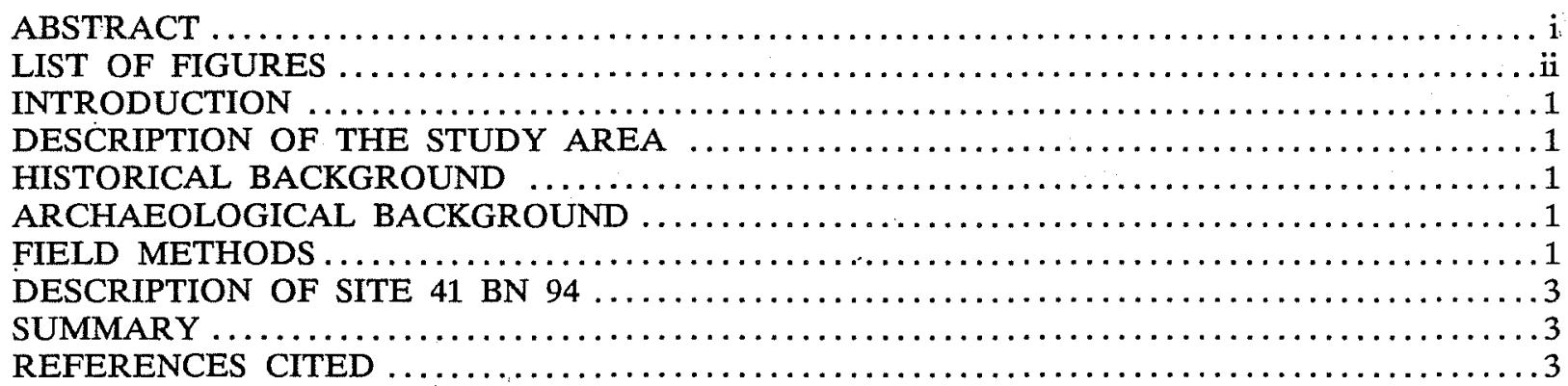

LIST OF FIGURES

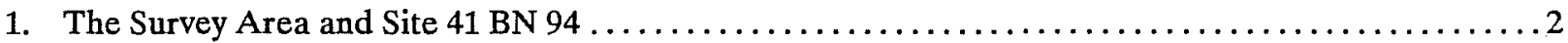




\section{INTRODUCTION}

On September 23, 1988, personnel from the Center for Archaeological Research, The University of Texas at San Antonio (CAR-UTSA), conducted a pedestrian archaeological survey and limited shovel testing at the 150-acre proposed Bandera City Park, Bandera County, Texas (Fig. 1). The work was conducted under contract between the City of Bandera and the CAR-UTSA. The purpose of the survey was to determine whether any cultural resources existed within the proposed park boundaries, and if there were, would they be suitable for nomination to the $\mathrm{Na}$ tional Register of Historic Places and to be designated as a State Archeological Landmark. The investigation was carried out by Ronald W. Burkett and Clint McKenzie of the Center staff. The project was conducted under Texas Antiquities Committee Permit No. 726. All work was completed under the general direction of Jack D. Eaton, acting director of the Center. All field notes, photographs, and drawings pertaining to this project are on file at the CAR-UTSA.

\section{DESCRIPTION OF THE STUDY AREA}

The study area is a 150-acre tract located within the city limits of Bandera. The park will comprise a $4 \mathrm{~km}$ inside curve of a horseshoe bend formed by the modern channel of the Medina River (Fig. 1). Approximately $65 \%$ of the park is situated in or alongside the northern bank of the current river channel, while the rest is some 6 to $10 \mathrm{~m}$ higher in elevation, but is still within the 100 -year floodplain.

Physiographically, the river channel and adjacent lowlands are within the Orif-Karnes Association (United States Department of Agriculture 1977). These areas are subject to short-term flooding several times a year in most years. Slopes are nearly level to undulating within short distances and are subject to change with each flood. There is some limestone outcropping and large expanses of exposed gravels and gravel bars. Soils are a calcareous fine sandy loam that contain in excess of $35 \%$ waterworn limestone pebbles.

The portion of the proposed park that is located on the higher river terrace is, or was, alluvium formed Frio Series calcareous, clayey soil. Either because of overgrazing or other modern alteration, much of this soil has eroded leaving a silty clay with a high density of waterworn limestone pebbles and chert cobbles. It is on this type of surface that the one prehistoric occupational site (41 BN 94) was found (Fig. 1).

\section{HISTORICAL BACKGROUND}

Bandera County was created out of Bexar County: in 1856 and was named for the Bandera Mountains located in the northern part of the county.

The first settlers were shingle makers who had settled on the Medina River in 1852. They laid out the town of Bandera in 1853, and this town eventually became the county seat. A sawmill was built to process lumber and shingles made out of the cypress trees that grew along the river and the other streams in the area. In 1854, a Mormon colony settled in the town and, in 1855,16 Polish families arrived to work in the sawmill (Webb 1952).

The county continued to grow slowly and by the 1980 census had a population of 7084 . Today, lumber products are still manufactured in Bandera, but $95 \%$ of the county's income is derived from agriculture. Agricultural activities are primarily the production of beef cattle, sheep, goats, and poultry (Kingston, editor 1983).

\section{ARCHAEOLOGICAL BACKGROUND}

The Bandera City Park site lies within the southwestern portion of the archaeological region known as central Texas (Suhm 1960; Weir 1976; Prewitt 1981). Although there are well over 400 archaeological sites recorded for Bandera County (only about 75 sites are registered in the Smithsonian Trinomial System), none are in the near vicinity of the city of Bandera (Labadie 1987). Therefore, the archaeology of the study area is poorly known. Research has shown that prehistoric peoples have occupied Bandera County from as early as the Paleo-Indian period. However, the majority of recorded sites that have been dated are from the Archaic period. Background on the region can be found in a report by Black and McGraw (1985). An archaeological review of Bandera County will be included in a report on site $41 \mathrm{BN} 33$ being prepared by the State Department of Highways and Public Transportation (Henderson, personal communication).

\section{FIELD METHODS}

The survey was conducted following the guidelines suggested by Hester, Heizer, and Graham (1975) and the guidelines of the Council of Texas Archeologists (1987).

Survey methods varied as dictated by terrain. An effort was made to reach all accessible portions of the present river channel, although large segments of the river bottom could not be effectively surveyed because of accumulations of flood debris and densely tangled 
This page has been

redacted because it

contains restricted

information. 
vegetation. All dirt roads, trails, and tracks in the river bottom and leading down to the river bottom were examined for eroding cultural materials. None were found.

The relatively level terrace between First and Third Streets and Pecan and Maple Streets was surveyed by 15-m intervals. This resulted in the identification of one site (41 BN 94) immediately to the southwest of the intersection of Hackberry and Second Streets. The results of one shovel test $\left(50 \mathrm{~cm}^{2}\right.$ dug to a depth of $40 \mathrm{~cm}$ ) were negative.

Additionally, two $50-\mathrm{cm}^{2}$ shovel tests were made in the area designated to be the visitor's center to the west of Cypress Street. Shovel test results were negative. Though there was no surface indication of cultural deposits, this is an area scheduled for construction activity.

\section{DESCRIPTION OF SITE 41 BN 94}

A single site was recorded during the survey. The following description is based on surface examination and one $50-\mathrm{cm}^{2}$ shovel test.

Type of Site: Prehistoric workshop area

Dimensions: The estimated site appears to be approximately $25 \times 60 \mathrm{~m}$, with the long axis running northwest to southeast.

Location: The site runs alongside and parallel to Second Street immediately across from its intersection with Hackberry Street, just north of the Medina River.

Topographic Context: The site is located on a relatively flat area on a river terrace. There is no outstanding topographic feature associated with the site.

Elevation: Approximately 1230 feet above mean sea level (msl)

Water Source: The site is located on a terrace 125 $\mathrm{m}$ from the Medina River.

Yegetation and Soil: The area of the site location has been cleared in the past and is now covered with low-growing native grasses and some juniper. The soil is composed of a medium brown silt with a high percentage of waterworn limestone pebbles and chert cobbles $2-5 \mathrm{~cm}$ in diameter.

Condition: The site is extensively disturbed. In addition to erosion, Second Street was built over part of the site. A residence was built just southeast of the site to replace an earlier one destroyed in the flood of 1978. The site area has been subjected to both extensive natural disturbance in the form of fluvial calcareous deposits and more modern colluvial slope wash.

Discussion: The site is identified as a low density lithic scatter, overlaying an area about $25 \times 60 \mathrm{~m}$. Lithic debris is estimated at approximately a single fragment per $25 \mathrm{~m}^{2}$. This site is immediately adjacent to and appears to be cut by Second Street. The scat- ter is composed of fire-reddened limestone, chert cobbles and debitage. Recovered were 27 primary, secondary, and tertiary chert flakes; two cores; two percussion-flaked scrapers; and three flakes exhibiting edge utilization. None of the chert fragments showed evidence of being waterworn. These cultural materials are permanently stored at the CAR-UTSA.

\section{SUMMARY}

There is no evidence that $41 \mathrm{BN} 94$ was anything other than a temporary lithic processing center or ephemeral (temporary) occupational site. No diagnostic artifacts were recovered, and no features were noted. Between the erosion of the topsoil, the deflation of the assemblage, and the impact of the construction of Second Street and the adjacent residence, it is extremely doubtful that any significant conclusions may be drawn from the existing scattered lithic debris.

It is possible, given the location, that a more deeply buried site could be present in the vicinity. Therefore it is recommended that should buried cultural resources be uncovered during developments, the Texas Antiquities Committee should be contacted.

Site 41 BN 94 is not considered eligible for nomination to the National Register of Historic Places or to be designated as a State Archeological Landmark.

\section{REFERENCES CITED}

Black, S. L. and A. J. McGraw

1985 The Panther Springs Creek Site: Cultural Change and Continuity Within the Upper Salado Creek Watershed, South-Central Texas. Center for Archaeological Research, The University of Texas at San Antonio, Archaeological Survey Report 100.

Council of Texas Archeologists

1987 Guidelines for Professional Performance Standards.

Hester, T. R., R. F. Heizer, and J. A. Graham

1975 Field Methods in Archaeology. 6th edition. Mayfield Publishing Company, Palo Alto, California.

Kingston, M. T., editor

1983 Texas Almanac. Dallas Morning News, Dallas. 
Labadie, J. H.

1987 A Reconnaissance of Electrical Transmission Line Rights-of-Way in Bandera and Kerr Counties, Texas. Center for Archaeological Research, The University of Texas at San Antonio, Archaeological Survey Report 164.

1981 Cultural Chronology in Central Texas. Bulletin of the Texas Archeological Society 52:65-89.

Suhm, D. A.

1960 A Review of Central Texas Archeology. Bulletin of the Texas Archeological Society 29:63-108.

United States Department of Agriculture

1977 Soil Survey of Bandera County, Texas.

Webb, W.P.

1952 The Handbook of Texas. Two volumes. The Texas State Historical Association, Austin.

Weir, F. A.

1976 The Central Texas Archaic. Ph.D. dissertation, Department of Anthropology, Washington State University, Pullman. University Microfilms, Ann Arbor. 
